Discussion Paper No. 14-057

\title{
Registered Cartels in Austria - Coding Protocol
}

Nikolaus Fink, Philipp Schmidt-Dengler, Konrad O. Stahl, and Christine Zulehner

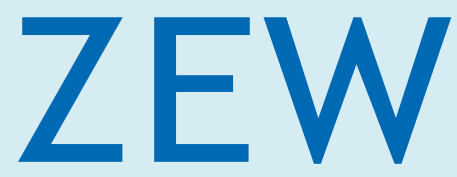

Zentrum für Europäische Wirtschaftsforschung $\mathrm{GmbH}$

Centre for European Economic Research 
Discussion Paper No. 14-057

\section{Registered Cartels in Austria - Coding Protocol}

Nikolaus Fink, Philipp Schmidt-Dengler, Konrad O. Stahl, and Christine Zulehner

Download this ZEW Discussion Paper from our ftp server:

http://ftp.zew.de/pub/zew-docs/dp/dp14057.pdf

Die Discussion Papers dienen einer möglichst schnellen Verbreitung von neueren Forschungsarbeiten des ZEW. Die Beiträge liegen in alleiniger Verantwortung der Autoren und stellen nicht notwendigerweise die Meinung des ZEW dar.

Discussion Papers are intended to make results of ZEW research promptly available to other economists in order to encourage discussion and suggestions for revisions. The authors are solely responsible for the contents which do not necessarily represent the opinion of the ZEW. 


\title{
Registered Cartels in Austria - Coding Protocol*
}

\author{
Nikolaus Fink, Philipp Schmidt-Dengler \\ Konrad O. Stahl, and Christine Zulehner ${ }^{\dagger}$
}

November 25, 2014

\begin{abstract}
In the period following WW II. until the country accessed the European Union, cartels were legalized in Austria, upon registration with the Austrian Cartel Court. We obtained access to the registration data, and scanned them all towards a microeconomic analysis of contracting behavior between firms competing, in principle, in their respective markets. In this paper, we give a detailed account of our procedure of coding the data from the scanned documents.
\end{abstract}

JEL classification: L410, L430

Keywords: Collusion, legal cartels, contracts

*We would like to thank the participants of the SEEK Workshops on Legal Cartels in Mannheim. We are grateful to Stefan Weingärtner for excellent research assistance. Financial support from the Jubiläumsfonds of the Austrian National Bank (grant number 14449) and the ZEW under the SEEK programme is gratefully acknowledged.

$\dagger$ N. Fink: Johannes Kepler University of Linz and Austrian Institute of Economic Research, Ch.Zulehner: Goethe University, Frankfurt and C.E.P.R.; P. Schmidt-Dengler: University of Vienna and C.E.P.R.;K. O. Stahl: University of Mannheim, C.E.P.R., and ZEW. E-Mail for correspondence: Nikolaus.Fink@wifo.ac.at 


\section{Contents}

1 Introduction 4

2 Data Generating Process and Coding Procedure 4

2.1 Institutional Background . . . . . . . . . . . . . . . . . 4

2.2 Data Sources . . . . . . . . . . . . . . . . . 5

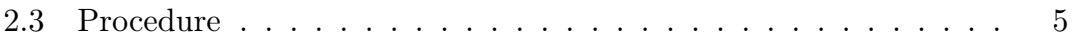

2.4 Variable Types . . . . . . . . . . . . . . . . . . 6

3 Summary Information on Cartels and Cartel Agreements 6 3.1 Cartel and Contract Identification . . . . . . . . . . . . . 6

3.2 Relevant Products and Geographical Area . . . . . . . . . . . . . 7

3.3 Cartel Participants and Length of Agreement . . . . . . . . . . 7

3.4 Start and End Dates of an Agreement . . . . . . . . . . . . . 8

3.5 Entries, Exits, and Mergers Involving Cartel Members . . . . . . 9

3.6 Industry Information . . . . . . . . . . . . . . . . . 10

4 Institutional Detail, Cartelists' Justifications, Procedural Aspects in Cartel Formation 11

4.1 Institutional Detail . . . . . . . . . . . . . . . . . . . . 11

4.2 Economic Justification for Cartel Formation . . . . . . . . . . . . 12

4.3 Cartel Review . . . . . . . . . . . . . . . . . . 13

5 Economics of the Cartel 14

5.1 Cartel Type . . . . . . . . . . . . . . . . . . . . . . . . . 14

5.2 Collusion Clauses . . . . . . . . . . . . . . . . . . . . . 14

5.3 Organization . . . . . . . . . . . . . . . . . 17

5.4 Information Exchange . . . . . . . . . . . . . . . . . 20

5.5 Compensation Schemes . . . . . . . . . . . . . . . 21

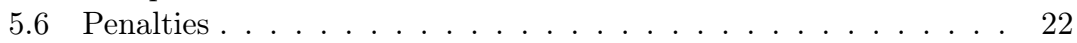

5.7 Entry into, and Exit from the Cartel . . . . . . . . . . . . . 23 


\section{List of Tables}

Identifiers for Cartels and Agreements . . . . . . . . . . . . . . 6

Relevant Product(s) and Markets . . . . . . . . . . . . 7

Number of Participants and Length of Cartel Agreement . . . . . 8

Start and End Dates . . . . . . . . . . . . . . 8

Voluntary Entry/Exit: Duration of the contract . . . . . . . . 9

Entries, Exits and Mergers . . . . . . . . . . . . . . . 9

Cartel Market Share . . . . . . . . . . . . . . . . . . . 10

Competitive Fringe Market Share . . . . . . . . . . . . . . . . . 10

Import Share . . . . . . . . . . . . . . . . . . . . . . 10

Institutional Details . . . . . . . . . . . . . . . 12

Economic Justification . . . . . . . . . . . . . . . . 13

Cartel Review: Requests by . . . . . . . . . . . . . . . . . 13

Cartel Review: Assessment and Changes required . . . . . . . . . 14

Cartel Type . . . . . . . . . . . . . . . . . . . . . 14

Clauses: Market Segmentation _. . . . . . . . . . . . . . 15

Clauses: Prices and Discounts . . . . . . . . . . . . . . . 16

Clauses: Capacity . . . . . . . . . . . . . . 16

Clauses: Vertical Exclusivity Restraints to Outsiders . . . . . . . 16

Clauses: Norms . . . . . . . . . . . . . . . . . . . . . . . . 17

Clauses: Other cooperation . . . . . . . . . . . 17

Clauses: Entry prevention . . . . . . . . . . . . . . 17

Organization: Decision-Making Bodies . . . . . . . . . . . . 18

Organization: Internal day-to-day Management . . . . . . . . . . 18

Organization: External support . . . . . . . . . . . . . 19

Organization: Responsibilities . . . . . . . . . . . . . . 19

Organization: Voting Rules (Required Majority in \%) . . . . . . 19

Organization: Voting Weights for the Cartel Object . . . . . . . 20

Information Exchange: Cartel-internal Auditing . . . . . . . . . 20

Information Exchange: Annual Internal Reporting Frequency . . 20

Information Exchange: Ex-ante Notification . . . . . . . . . . . 21

Information Exchange: Ex-post Notification . . . . . . . . . . 21

Information Exchange: Sales vs. Exports . . . . . . . . . . . . 21

Compensation Schemes . . . . . . . . . . . . . . . . 21

Non-Monetary Penalties . . . . . . . . . . . . . . . . . 22

Absolute Penalties . . . . . . . . . . . . . . . . 22

Relative penalties (Upper Limits, in percent of) . . . . . . . . . 22

Penalties: Security deposits . . . . . . . . . . . . . 23

38 Voluntary Entry/Exit: Rules for Entry . . . . . . . . . . . . . . . . . 23

39 Voluntary Entry/Exit: Rules for Exit . . . . . . . . . . . 23 


\section{Introduction}

From 1951 on, Austrian law foresaw that cartels were legalized by notification to a cartel registry. The cartels were legal once the registration was approved. With Austria's accession to the European Community, European competition law had to be applied. Thus, from 1995 on, the approval of cartels was restricted to comply with E.U. competition law and the European Commission started to ensure the application.

The first entries into the cartel registry we found are from $1973 .{ }^{1}$ The last entry into the registry was in 2002.

We developed a coding protocol to format the information available mainly from the contracts archived in the cartel registry. In Section 2 we describe the institutional background, the data sources and how we proceeded. In the ensuing Sections 3-5 we specify and explain the categories we have chosen. In Section 3, we categorize general descriptives; in Section 4 the economic justifications given by the cartelists when applying for registration, and procedural aspects related to the latter; and in Section 5 the main economic characteristics.

\section{Data Generating Process and Coding Proce- dure}

Cartels had to be approved upon an application, including a justification of the initiative to create a cartel, and the proposed cartel contract. Also, prices were monitored, and in most sectors, price changes had to be approved by public authorities. Here we briefly describe the procedures involved, and the data available on the cartels. Then we explain how we developed the categories for coding the data.

\subsection{Institutional Background}

The Cartel Court (CC) had to approve any application to form, and to continue a cartel. As much as we know of, it always did so when the recommendation by the 'Parity Committee on Cartel Matters', consisting of representatives of companies and labor ("Paritätischer Ausschuss für Kartellangelegenheiten"), was positive.

In order to understand economic policy in Austria in the relevant time period, it is central to know that interest group influence in Austria was institutionalized via the chambers of commerce, labor and agriculture that, respectively, represent companies, workers and farmers. Membership was compulsory. These three chambers and the Austrian Trade Union Federation form the so-called social partners. The chambers represent membership interests at all levels of government. For the relevant time period, social partners had a decisive influence on economic policy in general. Consensus-decision making was the rule.

\footnotetext{
${ }^{1}$ Older entries no longer exist.
} 
Thus even an informal common position of the social partners was taken seriously by industry.

In addition to the right of the chambers of labor and commerce to appoint the members of the Parity Committee, all three chambers as well as the Federal Financial Agency ("Finanzprokuratur") were parties of the proceedings. ${ }^{2}$ This included the right to ask for an in-depth review of the application and for additional information on each cartel.

Distinct from the Parity Committee, a 'Parity Commission' ("Paritätische Kommission") consisting of all four social partners was in charge of monitoring prices, and with this at least in part also monitored the cartelists' price formation. Typically industry representatives submitted a proposed price increase and provided cost data to justify that price increase. The Parity Commission then approved or rejected the price increase. ${ }^{3} \mathrm{~A}$ common position of all members of the Parity Commission was taken seriously by the companies, and prices were not increased above the approved levels. ${ }^{4}$ In effect, the proceedings leading to the application for price hikes allowed for collusive pricing arrangements, as long as these arrangements were stable and thus did not require more elaborate clauses such as punishment in case of downward deviation from the agreed upon price.

\subsection{Data Sources}

All documents archived in the Cartel Court were made available to us. These documents include the cartel contracts as proposed by the participants, as well as additional documentation. ${ }^{5}$ The scope of the archived additional documents varies and includes applications to form, to continue, and to terminate a cartel as well as judicial approval decrees. Also available are the annual reports of the Parity Committee that summarize its activity and its most important decisions.

\subsection{Procedure}

We scanned the material available in some 125 folders archived in the Cartel Court's registry, including additional documentation on entries, mergers and exits and on economic data on the cartels. ${ }^{6}$ We also scanned the annual reports of the Joint Committee for economic data on the cartels. We so far did not reconstruct the approved absolute price increases that are documented mostly as relative price increases in the minutes of the price determination proceedings.

\footnotetext{
${ }^{2}$ The Federal Financial Agency represents the federal government in a court of law.

${ }^{3}$ Effectively the Subcommittee for Prices ("Preisunterausschuss") was in charge of monitoring prices.

${ }^{4}$ Some cartels were explicitly formed to maintain prices at the approved level.

${ }^{5}$ According to officials, the archive is not complete. Some agreements and additional documents were taken out and not returned.

${ }^{6}$ Here we consider all documents archived in the Cartel Court. In fact, some contain vertical agreements between one upstream firm and its downstream partners, that we consider to involve pure vertical restraints rather than cartel arrangements.
} 
We coded the information contained in the contracts we felt most pertinent in about 200 categories.

\subsection{Variable Types}

The coding mostly involves binary variables. If a contract clause as specified in the code is included in the agreement, we enter a " 1 ". A " 0 " is entered otherwise. Note that there may have been clauses the cartelists agreed upon informally, that are not contained in the formal agreement. Hence a "0" does not necessarily imply that the relevant clause was not part of the cartel arrangement. In some situations we use nominal categories. We use, for example, the official statistical industry classification scheme ÖNACE (Austrian NACE) to classify the activity of the cartel. Dates, frequencies etc. are numerically coded. Finally, for some information, we use a text format - for example for the products involved, detailing the statistical industry classification.

\section{Summary Information on Cartels and Cartel Agreements}

\subsection{Cartel and Contract Identification}

In Table 1, under 1.1, we assign a running number to each cartel. A cartel might be organized on the basis of a series of subsequent or adjacent agreements ${ }^{7}$, contained in one or more folders as deposited in the Cartel Court. Under 1.2, we assign a running identification number after the cartel identifier. For instance, 3.5 signifies the fifth consecutive cartel agreement of the cartel with the running number three. Under 1.3, we assign a short english subject title to the cartel that aims to adress the relevant products and/or services and the relevant area.

In the Cartel Court registry, the individual agreements are contained in folders under possibly differing registry numbers, indicated for each contract under 1.4.

Table 1: Identifiers for Cartels and Agreements

\begin{tabular}{|l|l|l|l|}
\hline $\mathbf{N r}$ & Name & Variable Type & Source \\
\hline 1.1 & cartel number & integer & assigned \\
\hline 1.2 & contract identification number & decimal & assigned \\
\hline 1.3 & title of the cartel & text & assigned \\
\hline 1.4 & cartel registry number & text & $\begin{array}{l}\text { CC folder } \\
\text { number }\end{array}$ \\
\hline
\end{tabular}

Henceforth all tabulations relate to a specific agreement, as indexed under 1.2 .

\footnotetext{
${ }^{7}$ For example, a paper producer agrees on a cartel with an already existing cartel in the paper industry.
} 


\subsection{Relevant Products and Geographical Area}

In Table 2 under 2.1 the products subject to the agreement are named in full text. Under 2.4 they are coded according to 4 -digit ÖNACE. ${ }^{8}$ Under 2.2, we take a best guess of whether the cartelized product(s) is/are potentially the only product(s) produced by the firms participating in the cartel. Under 2.3, we code the regional (subnational) or export market in case the cartel does not cover the national Austrian market. Note that with this code, we can identify any changes in products and/or markets served by the very cartel.

Some cartel contracts involve firms in two vertically related industries. In this case, we note, under 2.5, the ÖNACE 4 digit classification for the downstream industry concerned.

Table 2: Relevant Product(s) and Markets

\begin{tabular}{|l|l|l|l|}
\hline $\mathbf{N r}$ & Name & Variable Type & Source \\
\hline 2.1 & products & text & agreement \\
\hline 2.2 & $\begin{array}{l}\text { no other products produced by } \\
\text { cartel firms (estimate) }\end{array}$ & binary & agreement \\
\hline 2.3 & market (if not Austria) & text & agreement \\
\hline 2.4 & $\begin{array}{l}\text { ONACE 4-digits (upstream, if } \\
\text { applicable) }\end{array}$ & nominal & assigned \\
\hline 2.5 & $\begin{array}{l}\text { Downstream ÖNACE 4-digits, if } \\
\text { applicable }\end{array}$ & nominal & assigned \\
\hline
\end{tabular}

\subsection{Cartel Participants and Length of Agreement}

In Table 3 we specify the number of firms involved in the cartel agreement under 3.1. If the contract involves vertically related firms, we sort into upstream and downstream firms. ${ }^{9}$ We take a best guess if that is unclear.

As a proxy for the complexity of the agreements, we take its number of pages.

\footnotetext{
${ }^{8}$ We use the ÖNACE 95 classification scheme. That scheme is the Austrian national implementation of NACE Revision 1. NACE Revision 1 was subject to EU legislation in 1990.

${ }^{9}$ In the case where the list of cartel participants was missing, the number of participants is taken from the additional documents.
} 
Table 3: Number of Participants and Length of Cartel Agreement

\begin{tabular}{|l|l|l|l|}
\hline $\mathbf{N r}$ & Name & Variable Type & Source \\
\hline 3.1 & $\begin{array}{l}\text { number of firms (upstream, if ap- } \\
\text { plicable) }\end{array}$ & integer \\
\hline 3.2 & $\begin{array}{l}\text { number of firms downstream (if } \\
\text { applicable) }\end{array}$ & integer & agreement \\
\hline 3.3 & $\begin{array}{l}\text { upstream/downstream allotment } \\
\text { estimate (if applicable) }\end{array}$ & binary & agreement \\
\hline 3.4 & $\begin{array}{l}\text { number of pages of the agree- } \\
\text { ment }\end{array}$ & integer & \\
\hline
\end{tabular}

\subsection{Start and End Dates of an Agreement}

In several instances, informal - or even formal - cartel agreements preceded the first agreement contained in the registry. In Table 4 we document the start and end dates of the cartel. Under 4.1 we code the date of any informal (oral) cartel arrangement between the cartelists, if mentioned in the first documented cartel agreement; under 4.2 we code the starting date for the first formal cartel arrangement ${ }^{10}$, and under 4.3 the date of the agreement under scrutiny.

As to the termination date of the registry folder ${ }^{11}$, we have two sources of information: a formal termination decision by the Cartel Court, or the termination date as found on the front page of the registry folder. ${ }^{12}$ Based on the cartel number and the termination date of the registry folder, we calculate the terminate date of the cartel.

Table 4: Start and End Dates

\begin{tabular}{|l|l|l|l|}
\hline $\mathbf{N r}$ & Name & Variable Type & Source \\
\hline 4.1 & first recorded starting date & date & agreement \\
\hline 4.2 & $\begin{array}{l}\text { starting date of first formal } \\
\text { agreement }\end{array}$ & date & agreement \\
\hline 4.3 & date of current agreement & date & agreement \\
\hline 4.4 & termination date of folder & date & $\begin{array}{l}\text { CC folder } \\
\text { CC decision }\end{array}$ \\
\hline 4.5 & termination date of cartel & date & calculated \\
\hline
\end{tabular}

In Table 5, we code information on the duration of the cartel agreement.

\footnotetext{
${ }^{10}$ We do not necessarily have documentation of that.

${ }^{11}$ There is one termination date for each cartel registry number. For those cartels that reappear in another registry folder, the cartel - identified by the cartel number - continues.

${ }^{12}$ In the latter case, we observe only the year. We took the 31st of December as the termination date.
} 
Table 5: Voluntary Entry/Exit: Duration of the contract

\begin{tabular}{|l|l|l|l|}
\hline $\mathbf{N r}$ & Name & Variable Type & Source \\
\hline 5.1 & $\begin{array}{l}\text { specified duration of agreement } \\
\text { in years }\end{array}$ & integer & agreement \\
\hline 5.2 & open-ended agreement & binary & agreement \\
\hline 5.3 & expiration date of the agreement & date & agreement \\
\hline
\end{tabular}

\subsection{Entries, Exits, and Mergers Involving Cartel Mem- bers}

Some cartels are described by consecutive contracts, drafted solely because firms entered, exited, or merged. In the cases in which these changes were mentioned explicitely, we have a complete account of the changes in cartel composition as based on all documents available heretofore. Otherwise, we did not record changes in the composition of the cartel between two contracts, but only the number of cartelists. This implies in particular that their composition could have changed at a constant size of the cartel. In Table 6 we note these changes in the number of cartelists. We record under 6.1 the number of firms that enter anew with the current agreement. In line 6.2 the respective entry dates are recorded. ${ }^{13}$ Under 6.3 and 6.4 , we proceed similarly for exits, and under 6.5 and 6.6 for mergers, respectively. Note that we code mergers only in the case they take place between two (or more) cartelists. Thus, a merger of one cartelist with one or more outsiders is not part of the code.

Table 6: Entries, Exits and Mergers

\begin{tabular}{|c|c|c|c|}
\hline $\mathrm{Nr}$ & Name & Variable Type & Source \\
\hline 6.1 & entry: number of new firms & integer & $\begin{array}{l}\text { additional } \\
\text { documents }\end{array}$ \\
\hline 6.2 & entry date & date & $\begin{array}{l}\text { additional } \\
\text { documents }\end{array}$ \\
\hline 6.3 & exit: number of firms & integer & $\begin{array}{l}\text { additional } \\
\text { documents }\end{array}$ \\
\hline 6.4 & exit date & date & $\begin{array}{l}\text { additional } \\
\text { documents }\end{array}$ \\
\hline 6.5 & $\begin{array}{l}\text { merger: reduction in number of } \\
\text { firms by }\end{array}$ & integer & $\begin{array}{l}\text { additional } \\
\text { documents }\end{array}$ \\
\hline 6.6 & merger date & date & $\begin{array}{l}\text { additional } \\
\text { documents }\end{array}$ \\
\hline
\end{tabular}

\footnotetext{
${ }^{13}$ Line 6.2 is repeated in case there are several entry, exit and merger dates.
} 


\subsection{Industry Information}

For some cartels, we found data on the percentage market share of the cartel, the percentage market share of the competitive fringe and the percentage import shares for the relevant product(s). This information is collected in Table 7. Here we differentiate explicitly between the three different sources agreement, additional documents and annual report. Table 8 contains comparable information on the competitive fringe (if it exists), and Table 9 on the import share of products in focus.

Table 7: Cartel Market Share

\begin{tabular}{|l|l|l|l|}
\hline $\mathbf{N r}$ & Name & Variable Type & Source \\
\hline 7.1 & cartel market share (agreement) & fraction & agreement \\
\hline 7.2 & $\begin{array}{l}\text { cartel market share (additional } \\
\text { documents) }\end{array}$ & fraction & $\begin{array}{l}\text { additional } \\
\text { documents }\end{array}$ \\
\hline 7.3 & $\begin{array}{l}\text { cartel market share (annual } \\
\text { report) }\end{array}$ & $\begin{array}{l}\text { fraction } \\
\text { report }\end{array}$ \\
\hline
\end{tabular}

Table 8: Competitive Fringe Market Share

\begin{tabular}{|c|c|c|c|}
\hline $\mathrm{Nr}$ & Name & Variable Type & Source \\
\hline 8.1 & $\begin{array}{l}\text { market share competitive fringe } \\
\text { (agreement) }\end{array}$ & fraction & agreement \\
\hline 8.2 & $\begin{array}{l}\text { market share competitive fringe } \\
\text { (additional documents) }\end{array}$ & fraction & $\begin{array}{l}\text { additional } \\
\text { documents }\end{array}$ \\
\hline 8.3 & $\begin{array}{l}\text { market share competitive fringe } \\
\text { (annual report) }\end{array}$ & fraction & $\begin{array}{l}\text { annual } \\
\text { report }\end{array}$ \\
\hline
\end{tabular}

Table 9: Import Share

\begin{tabular}{|l|l|l|l|}
\hline $\mathbf{N r}$ & Name & Variable Type & Source \\
\hline 9.1 & $\begin{array}{l}\text { market share imports (agree- } \\
\text { ment) }\end{array}$ & fraction & agreement \\
\hline 9.2 & $\begin{array}{l}\text { market share imports (additional } \\
\text { documents) }\end{array}$ & fraction & $\begin{array}{l}\text { additional } \\
\text { documents }\end{array}$ \\
\hline 9.3 & $\begin{array}{l}\text { market share imports (annual } \\
\text { report) }\end{array}$ & $\begin{array}{l}\text { fraction } \\
\text { report }\end{array}$ \\
\hline
\end{tabular}




\section{Institutional Detail, Cartelists' Justifications, Procedural Aspects in Cartel Formation}

\subsection{Institutional Detail}

We want to get a full picture of the cartel duration over several successive agreements. In Table 10, we code under 10.1 whether there is a precursory agreement. Under 10.2, we record the identification number of the precursory agreement in case it is part of our documentation at hand, and under 10.3 we record the end date of the precursory agreement. ${ }^{14}$ As a double check, we also ask for the identification number of the subsequent agreement. The termination date of the registry folder and thus the last agreement in the folder is coded above under 4.4. Under 10.5 we specify reasons for its termination, inasmuch given.

Observe that the termination date of the last agreement coincides with the termination of the cartel. Under 10.6 we ask whether the cartel specified in the current agreement is connected to any other cartel; if yes, that cartel's registry number is documented here. Finally, we code under 10.7 the name of the lawyer in charge of the agreement; mostly this individual was also the authorized representative of the cartel in court. ${ }^{15}$

Continuing on the institutional context, we code under 10.8 and 10.9 , respectively, reference in the contract to one of the two common forms of price regulation during the period of the cartels: Official price regulation as done by the ministries, and price changes as approved by the Parity Commission.

At last, we note whether a cartel was registered as bagatelle cartel. Such a cartel did not need to register since it was below a legal threshold. But some cartels still registered - presumably to make the contract binding.

\footnotetext{
${ }^{14}$ The start date of the precursory agreement is coded in the code for that agreement.

${ }^{15}$ We took the name of the first lawyer. If there were several lawyers, we took note of them in an additional field.
} 
Table 10: Institutional Details

\begin{tabular}{|l|l|l|l|}
\hline $\mathbf{N r}$ & Name & Variable Type & Source \\
\hline 10.1 & $\begin{array}{l}\text { precursory agreement if men- } \\
\text { tioned }\end{array}$ & binary & agreement \\
ID-number of precursory & nominal & $\begin{array}{l}\text { assigned } \\
\text { ID-number }\end{array}$ \\
\hline 10.2 & $\begin{array}{l}\text { end date of precursory } \\
\text { agreement if documented }\end{array}$ & date & $\begin{array}{l}\text { precursory } \\
\text { agreement }\end{array}$ \\
\hline 10.4 & $\begin{array}{l}\text { ID number of subsequent } \\
\text { agreement, if documented }\end{array}$ & nominal & $\begin{array}{l}\text { assigned } \\
\text { ID-number }\end{array}$ \\
\hline 10.5 & reason for termination & text & $\begin{array}{l}\text { additional } \\
\text { documents }\end{array}$ \\
\hline 10.6 & reference to other cartels & text & $\begin{array}{l}\text { cartel regi- } \\
\text { stry number }\end{array}$ \\
\hline 10.7 & $\begin{array}{l}\text { lawyer in charge of the } \\
\text { agreement }\end{array}$ & $\begin{array}{l}\text { additional } \\
\text { documents }\end{array}$ \\
\hline 10.8 & official price regulation & binary & agreement \\
\hline 10.9 & $\begin{array}{l}\text { price regulation via Parity Com- } \\
\text { mission }\end{array}$ & binary & agreement \\
\hline 10.10 & bagatelle cartel & binary & $\begin{array}{l}\text { additional } \\
\text { documents }\end{array}$ \\
\hline
\end{tabular}

\subsection{Economic Justification for Cartel Formation}

Upon application the cartelists were required to provide a justification for the formation of the cartel. Whereas this may have involved the production of lyrics, it is interesting to document the market deficiencies the cartelists aim to resolve within a co-operative arrangement. The categories are self-explanatory, but the specific wording in the application might require some interpretation. Multiple answers are possible. ${ }^{16}$

\footnotetext{
${ }^{16}$ Some economic justications are taken from the additional documents, too.
} 
Table 11: Economic Justification

\begin{tabular}{|l|l|l|l|}
\hline $\mathbf{N r}$ & Name & Variable Type & Source \\
\hline 11.1 & cut-throat competition & binary & agreement \\
\hline 11.2 & $\begin{array}{l}\text { excessive seller power to the car- } \\
\text { tel }\end{array}$ & binary & agreement \\
\hline 11.3 & $\begin{array}{l}\text { excessive buyer power from the } \\
\text { cartel }\end{array}$ & binary & agreement \\
\hline 11.4 & lack of security of supply & binary & agreement \\
\hline 11.5 & lack of job security & binary & agreement \\
\hline 11.6 & $\begin{array}{l}\text { lack of organization of the mar- } \\
\text { ket }\end{array}$ & binary & agreement \\
\hline 11.7 & excessive foreign competition & binary & agreement \\
\hline 11.8 & $\begin{array}{l}\text { lack of international competitive- } \\
\text { ness }\end{array}$ & binary & agreement \\
\hline 11.9 & lack of quality of products & binary & agreement \\
\hline 11.10 & excessive transport costs & binary & agreement \\
\hline 11.11 & excessive marketing costs & binary & agreement \\
\hline 11.12 & lack of economies of scale & binary & agreement \\
\hline 11.13 & lack of economies of scope & binary & agreement \\
\hline 11.14 & $\begin{array}{l}\text { lack of distributive justice (only } \\
\text { in vertical agreements }\end{array}$ & binary & agreement \\
\hline 11.15 & $\begin{array}{l}\text { lack of transparency of competi- } \\
\text { tion }\end{array}$ & binary & agreement \\
\hline
\end{tabular}

\subsection{Cartel Review}

As mentioned before, the cartel application was sometimes subject to a review. We differentiate between review requests by the four parties - the chambers of commerce, labor and agriculture as well as the federal financial agency ("Finanzprokuratur").

Table 12: Cartel Review: Requests by

\begin{tabular}{|l|l|l|l|}
\hline $\mathbf{N r}$ & Name & Variable Type & Source \\
\hline 12.1 & chamber of labor & binary & $\begin{array}{l}\text { additional } \\
\text { documents }\end{array}$ \\
\hline 12.2 & federal financial agency & binary & $\begin{array}{l}\text { additional } \\
\text { documents }\end{array}$ \\
\hline 12.3 & chamber of commerce & binary & $\begin{array}{l}\text { additional } \\
\text { documents }\end{array}$ \\
\hline 12.4 & chamber of agriculture & binary & $\begin{array}{l}\text { additional } \\
\text { documents }\end{array}$ \\
\hline
\end{tabular}

Sometimes the Parity Committee required changes in the proposed cartel contract. We summarize such changes in Table 13. We specify under 13.1 
whether the registration procedure led to changes in the agreement, and code under 13.2 reasons for the changes. For example, in later years the Parity Committee often dictated a time limit for the cartels. Furthermore, we code if disagreement in the Parity Committee on the proposed cartel contract could be observed. A disagreement left the decision on approval to the court. The court normally did not oppose the cartel without a supporting unanimous expert opinion of the Parity Committee. So the court was very likely to finally approve the cartel.

Table 13: Cartel Review: Assessment and Changes required

\begin{tabular}{|l|l|l|l|}
\hline $\mathbf{N r}$ & Name & Variable Type & Source \\
\hline 13.1 & change of the agreement & binary & $\begin{array}{l}\text { additional } \\
\text { documents }\end{array}$ \\
\hline 13.2 & reason for the change & text & $\begin{array}{l}\text { additional } \\
\text { documents }\end{array}$ \\
\hline 13.3 & disagreement & binary & $\begin{array}{l}\text { additional } \\
\text { documents }\end{array}$ \\
\hline
\end{tabular}

\section{Economics of the Cartel}

\subsection{Cartel Type}

In Table 14, we distinguish between four cartel types. Do the members restrict and cooperate buying, selling, importing oder exporting? Multiple answers are permitted. For example, an agreement might contain a buyer and a seller cartel. ${ }^{17}$

Table 14: Cartel Type

\begin{tabular}{|l|l|l|l|}
\hline $\mathbf{N r}$ & Name & Variable Type & Source \\
\hline 14.1 & buyer cartel & binary & agreement \\
\hline 14.2 & seller cartel & binary & agreement \\
\hline 14.3 & import cartel & binary & agreement \\
\hline 14.4 & export cartel & binary & agreement \\
\hline
\end{tabular}

\subsection{Collusion Clauses}

There are various ways for cartels to segment the market. The simplest and most common are quotas per firm and exclusive territories. Other forms of market segmentation involve the cartel members' production, so that the output of specific firms is restricted to specific products; or specialization on the market side

\footnotetext{
${ }^{17}$ Table 14 does not distinguish on its own between a group of firms that cartelize on purchase of an input and on selling of an output and two groups of firms where one group sells a product and a second group purchases the same product within one agreement.
} 
supplied to or supplied from. We unify the latter into customer/supplier specialization not involving exclusive territories and least freight-cost based allocation of orders to firms. All of this is done in Table 15.

Table 15: Clauses: Market Segmentation

\begin{tabular}{|l|l|l|l|}
\hline $\mathbf{N r}$ & Name & Variable Type & Source \\
\hline 15.1 & sales/purchasing quota & binary & agreement \\
\hline 15.2 & exclusive territories & binary & agreement \\
\hline 15.3 & product specialization & binary & agreement \\
\hline 15.4 & customer/supplier specialization & binary & agreement \\
\hline 15.5 & $\begin{array}{l}\text { least freight-cost based alloca- } \\
\text { tion }\end{array}$ & binary & agreement \\
\hline
\end{tabular}

Table 16 contains alternative pricing arrangements. A cartel for one homogenous product can involve a fixed price, a price floor, a price ceiling or a combination of a price floor and a price ceiling. These categories are considered mutually exclusive. More complex arrangements involve price books. A price book is a list of prices for different components contained in differentiated products. The purchase price is then calculated by taking the sum of quantity weigthed prices of these components.

We separately code arrangements on quantity and sales channels discounts as well as payment conditions and price conditional on distance, in order to grasp essential other factors that influence the final price.

Finally, the cartelists' liability for sales agents captures all different ways to circumvent the cartel via promotion of sales by any kind of sales agents.

The formation of cartel prices and price changes may be linked to that of input prices or prices of related goods. We distinguish between first a price adjustment clause, where the price depends on (an) external price(s) for (an) input(s) or an alternative good and is automatically adjusted; second, a common costing sheet private to the cartel, based on an internal price book that defines which costs have to be considered for calculating the price; and third, price formation based on average cost and change in cost data as reported by the cartelists. 
Table 16: Clauses: Prices and Discounts

\begin{tabular}{|l|l|l|c|}
\hline $\mathbf{N r}$ & Name & Variable Type & Source \\
\hline 16.1 & fixed price & binary & agreement \\
\hline 16.2 & price floor & binary & agreement \\
\hline 16.3 & price ceiling & binary & agreement \\
\hline 16.4 & price floor and ceiling & binary & agreement \\
\hline 16.5 & price book & binary & agreement \\
\hline 16.6 & quantity discounts & binary & agreement \\
\hline 16.7 & sales channels discounts & binary & agreement \\
\hline 16.8 & payment conditions & binary & agreement \\
\hline 16.9 & price conditional on distance & binary & agreement \\
\hline 16.10 & liability for sales agents & binary & agreement \\
\hline 16.11 & price adjustment clause & binary & agreement \\
\hline 16.12 & common costing sheet & binary & agreement \\
\hline 16.13 & price based on average cost & binary & agreement \\
\hline
\end{tabular}

Capacity restrictions the cartelists commit to in the contract are an obvious clause to constrain industry output and with it, to enforce higher prices. In Table 17, we distinguish between restrictions on investment into a new plant or in another firm, as well as enforcement of layoffs of plants, and restrictions on the diversion of capacity to non cartelists.

Table 17: Clauses: Capacity

\begin{tabular}{|l|l|l|l|}
\hline $\mathbf{N r}$ & Name & Variable Type & Source \\
\hline 17.1 & restriction on capacity & binary & agreement \\
\hline 17.2 & $\begin{array}{l}\text { restriction on capacity diversion } \\
\text { to non cartelists }\end{array}$ & binary & agreement \\
\hline
\end{tabular}

Some contracts include restrictions of the type that firms downstream or upstream are forced to trade exclusively with cartelists. In Table 18, we call this exclusivity in distribution or purchase.

Table 18: Clauses: Vertical Exclusivity Restraints to Outsiders

\begin{tabular}{|l|l|l|l|}
\hline $\mathbf{N r}$ & Name & Variable Type & Source \\
\hline 18.1 & exclusivity in distribution & binary & agreement \\
\hline 18.2 & exclusivity in purchase & binary & agreement \\
\hline
\end{tabular}

As to norms, we distinguish, in Table 19, between official norms that are exogenous to the cartel, ${ }^{18}$ and lot size that define the packaging size, ${ }^{19}$ as well as standardization of product quality endogenous to the cartel.

\footnotetext{
${ }^{18}$ Typically, a standard-setting body defines official norms.

${ }^{19}$ Bundling is not included in this category.
} 
Table 19: Clauses: Norms

\begin{tabular}{|l|l|l|l|}
\hline $\mathbf{N r}$ & Name & Variable Type & Source \\
\hline 19.1 & official norms & binary & agreement \\
\hline 19.2 & lot size & binary & agreement \\
\hline 19.3 & $\begin{array}{l}\text { standardization of product qual- } \\
\text { ity }\end{array}$ & binary & agreement \\
\hline
\end{tabular}

Some cartel contracts contain clauses involving the cooperation between cartelists on other than prices or quantities - in particular on R\&D and on advertising. Their existence is coded in summarized form, in Table 20.

Table 20: Clauses: Other cooperation

\begin{tabular}{|l|l|l|l|}
\hline $\mathbf{N r}$ & Name & Variable Type & Source \\
\hline 20.1 & joint research and development & binary & agreement \\
\hline 20.2 & joint advertising & binary & agreement \\
\hline
\end{tabular}

Entry prevention captures different forms of aggressive behavior against new entrants. In Table 21, we distinguish between individual entry prevention where one member is allowed to deviate from the agreement to prevent entry, and collective entry prevention where all members react.

Table 21: Clauses: Entry prevention

\begin{tabular}{|l|l|l|l|}
\hline $\mathbf{N r}$ & Name & Variable Type & Source \\
\hline 21.1 & individual entry prevention & binary & agreement \\
\hline 21.2 & collective entry prevention & binary & agreement \\
\hline
\end{tabular}

We did not code as yet clauses that appeared very rarely. Thus, we did not categorize trading conditions like limitation on warranty, restrictions on exchange, return policies, and on commission and consignment stocks. Furthermore, we did not classify various constraints on non-price competition like timing of price changes, introduction of new product categories, obligatory patents for brands, and restrictions on private labels, advertising and bundling. At last, we did not code further joint activities like joint cashing and the promotion of working and bidding consortia.

\subsection{Organization}

The internal organization of the cartels varied substantively. In Table 22, we distinguish first between a variety of decision making bodies: the plenary meeting where all members of the cartel participate, a committee where less than all but more than one cartel member participates, and a sole executive officer. Furthermore, we propose a category for an authorized representative ("Kartell- 
bevollmaechtigter") who is assigned tasks ${ }^{20}$ that go beyond the legally foreseen representation in court. ${ }^{21}$ Finally, we consider a particularly important category, called 'arbitration panel'. Normally, in such a panel the two opposing parties each appoint an arbitrator. These two will select an additional arbitrator as a chairman of the tribunal.

Table 22: Organization: Decision-Making Bodies

\begin{tabular}{|l|l|l|l|}
\hline $\mathbf{N r}$ & Name & Variable Type & Source \\
\hline 22.1 & plenary meeting & binary & agreement \\
\hline 22.2 & committee & binary & agreement \\
\hline 22.3 & executive officer & binary & agreement \\
\hline 22.4 & authorized representative & binary & agreement \\
\hline 22.5 & arbitration panel & binary & agreement \\
\hline
\end{tabular}

The internal day-to-day management of the cartels was also organized in various ways. In Table 23, we distinguish between an internal staffed office ${ }^{22}$ or management by a (leading) cartel member. Newly founded firms may also be part of the day-do-day management. We distinguish between exclusive and non exclusive joint sales companies organizing the downstream market for the cartel. Exclusive means that all output of all cartelists is sold via the joint sales company.

Table 23: Organization: Internal day-to-day Management

\begin{tabular}{|l|l|l|l|}
\hline $\mathbf{N r}$ & Name & Variable Type & Source \\
\hline 23.1 & staffed office & binary & agreement \\
\hline 23.2 & leading cartel member & binary & agreement \\
\hline 23.3 & exclusive joint sales company & binary & agreement \\
\hline 23.4 & $\begin{array}{l}\text { non exclusive joint sales com- } \\
\text { pany }\end{array}$ & binary & agreement \\
\hline
\end{tabular}

Additional external support to the cartel can be given by an independent auditor, an external trustee monitoring the agreement and providing the necessary or the relevant trade association. ${ }^{23}$

\footnotetext{
${ }^{20}$ For example, producers and importers of pharmaceuticals agreed on the rule that the authorized representative was in charge of investigations on infringements and imposing penalties.

${ }^{21}$ The authorized representative represents the cartel in the proceedings to register the cartel.

${ }^{22}$ This might also be a specific limited liability company. In the paper industry one limited liability company managed several cartels at the same time.

${ }^{23}$ For example, the trade association can nominate a member of the arbitration panel.
} 
Table 24: Organization: External support

\begin{tabular}{|l|l|l|l|}
\hline $\mathbf{N r}$ & Name & Variable Type & Source \\
\hline 24.1 & independent auditor & binary & agreement \\
\hline 24.2 & external trustee & binary & agreement \\
\hline 24.3 & trade association involved & binary & agreement \\
\hline
\end{tabular}

As to decisions that involve votings, ${ }^{24}$ we differentiate, in Table 25 , between different issues and relate them to the decision making bodies coded in Table 22. First, the cartel may fix total output/prices, or their change. ${ }^{25}$ Second, decisions involving the admission of firms to, and their exclusion from the cartel need to be taken. Third, penalties for deviating cartel members need to be determined. This is a particularly contested issue. It often involves several levels in a decision hierarchy that possibly are employed consecutively. We code the supreme decision-making body on these penalties. In the last entry of Table 25 , we denote the number of these bodies as specified in the cartel agreement.

Table 25: Organization: Responsibilities

\begin{tabular}{|l|l|l|c|}
\hline $\mathbf{N r}$ & Name & Variable Type & \\
\hline 25.1 & output & entries Table 22 & agreement \\
\hline 25.2 & price & entries Table 22 & agreement \\
\hline 25.3 & approval of entry & entries Table 22 & agreement \\
\hline 25.4 & exclusion & entries Table 22 & agreement \\
\hline 25.5 & $\begin{array}{l}\text { penalties (supreme decision- } \\
\text { making body) }\end{array}$ & entries Table 22 & agreement \\
\hline 25.6 & levels of jurisdiction for penalties & integer & agreement \\
\hline
\end{tabular}

Next we ask for the required majority for the first four decision categories involved in Table 25.

Table 26: Organization: Voting Rules (Required Majority in \%)

\begin{tabular}{|l|l|l|l|}
\hline $\mathbf{N r}$ & Name & Variable Type & Source \\
\hline 26.1 & output & numeric & agreement \\
\hline 26.2 & price & numeric & agreement \\
\hline 26.3 & approval of entry & numeric & agreement \\
\hline 26.4 & exclusion & numeric & agreement \\
\hline
\end{tabular}

As to the voting weights individual members of the voting body can carry, we simply distinguish between one member one vote, weighted voting power, e.g. according to output, sales, capacity or employees and a mixing variant

\footnotetext{
${ }^{24}$ We do not analyze the voting on the cartel contract itself: It has to be signed by all members - thus unanimity is required.

${ }^{25}$ c.f. Tables 14 and 15 , respectively. Note that quotas necessarily require fixing aggregate output.
} 
including per capita and and per weight voting power. We do not differentiate between different voting weights for different decisions.

Table 27: Organization: Voting Weights for the Cartel Object

\begin{tabular}{|l|l|l|l|}
\hline $\mathbf{N r}$ & Name & Variable Type & Source \\
\hline 27.1 & one member one vote & binary & agreement \\
\hline 27.2 & weighted voting power & binary & agreement \\
\hline 27.3 & $\begin{array}{l}\text { mixed voting power (per capita } \\
\text { and per weight) }\end{array}$ & binary & agreement \\
\hline
\end{tabular}

\subsection{Information Exchange}

As the cartel members potentially compete with each other and thus almost always have incentives to deviate from the cartel arrangement, a key issue in the organization of a cartel involves the provision of information by the cartel members, and the monitoring of that information provision. The contracts therefore include quite elaborate reporting requirements for the cartelists, as naturally related to the clauses employed in the cartel. In Table 28, we distinguish between rules involving mutual information provision, and those involving reporting to a central body.

Table 28: Information Exchange: Cartel-internal Auditing

\begin{tabular}{|l|l|l|l|}
\hline $\mathbf{N r}$ & Name & Variable Type & Source \\
\hline 28.1 & $\begin{array}{l}\text { mutual information between all } \\
\text { members }\end{array}$ & binary & agreement \\
\hline 28.2 & information to a central body & $\begin{array}{l}\text { entries } \\
\text { Tables 22, 23, 24 }\end{array}$ & agreement \\
\hline
\end{tabular}

The periodicity of required reporting rules from the cartelists to the central body indicates the intensity at which the cartel's economic activity is monitored by some central body. In Table 29 we code the frequency per year at which cartelists are required to provide data on quantities, revenues and exports, respectively. In addition, we code the annual frequency of reports from the cartel management back to the individual cartel members.

Table 29: Information Exchange: Annual Internal Reporting Frequency

\begin{tabular}{|l|l|l|l|}
\hline $\mathbf{N r}$ & Name & Variable Type & Source \\
\hline 29.1 & quantity & integer & agreement \\
\hline 29.2 & revenues & integer & agreement \\
\hline 29.3 & exports & integer & agreement \\
\hline 29.4 & $\begin{array}{l}\text { report by management to mem- } \\
\text { bers }\end{array}$ & integer & agreement \\
\hline
\end{tabular}


In some cases, the cartelists are required to report demand and/or supply before it is exercised. One reason is that the cartel wanted full control over the payment or any other delivery conditions. This is coded in Table 30.

Table 30: Information Exchange: Ex-ante Notification

\begin{tabular}{|l|l|l|l|}
\hline $\mathbf{N r}$ & Name & Variable Type & Source \\
\hline 30.1 & ex-ante demand & binary & agreement \\
\hline 30.2 & ex-ante supply & binary & agreement \\
\hline
\end{tabular}

Much more frequent are reports ex-post to the cartel management. In Table 31 we distinguish between reports on individual and aggregate sales of the typical cartelist.

Table 31: Information Exchange: Ex-post Notification

\begin{tabular}{|l|l|l|l|}
\hline $\mathbf{N r}$ & Name & Variable Type & Source \\
\hline 31.1 & individual sales & binary & agreement \\
\hline 31.2 & aggregate sales & binary & agreement \\
\hline
\end{tabular}

In Table 32 we distinguish between accounting requirements for sales in general, and specifically for exports. The latter is important in view of the incentive to cirvumvent a sales quota via re-imports.

Table 32: Information Exchange: Sales vs. Exports

\begin{tabular}{|l|l|l|l|}
\hline $\mathbf{N r}$ & Name & Variable Type & Source \\
\hline 32.1 & sales & binary & agreement \\
\hline 32.2 & exports & binary & agreement \\
\hline
\end{tabular}

\subsection{Compensation Schemes}

All sharing rules, e.g. quotas or profits, are typically specified ex ante, and not (exactly) realized ex post. In Table 33 we distinguish between several compensation mechanisms for deviations from the agreement so generated within a certain period. ${ }^{26}$ Multiple answers are possible.

Table 33: Compensation Schemes

\begin{tabular}{|l|l|l|l|}
\hline $\mathbf{N r}$ & Name & Variable Type & Source \\
\hline 33.1 & carry-over to the next period & binary & agreement \\
\hline 33.2 & cash payments & binary & agreement \\
\hline 33.3 & sales between cartelists & binary & agreement \\
\hline 33.4 & transfer of customers or orders & binary & agreement \\
\hline 33.5 & earnings redistribution & binary & agreement \\
\hline
\end{tabular}

\footnotetext{
${ }^{26}$ The period considered may vary between two months and a year.
} 


\subsection{Penalties}

Penalties punish a cartel member for a deviation from the agreement. The penalties specified in our contracts are surprisingly varied. Our code reflects only a first cut into a larger pie worth detailed investigation.

In Table 34, we distinguish between different forms of non-monetary penalties. For vertical cartels, the refusal to deal by the upstream or downstream industry sanctions the firm in the opposite industry.

Table 34: Non-Monetary Penalties

\begin{tabular}{|l|l|l|l|}
\hline $\mathbf{N r}$ & Name & Variable Type & Source \\
\hline 34.1 & warning & binary & agreement \\
\hline 34.2 & exclusion from the cartel & binary & agreement \\
\hline 34.3 & refusal to deal & binary & agreement \\
\hline
\end{tabular}

Monetary penalties may be specified in absolute terms; or related to economic variables, in particular the (absolute or percentage wise) deviation from magnitudes specified in the contract. In Table 35, we consider absolute penalties (in Austrian Schillings (ATS)), and in Table 36 relative penalties. Both are related to different forms of deviating from the cartel contract. In Table 35, we code the maximal penalties specified in the cartel contract.

Table 35: Absolute Penalties

\begin{tabular}{|l|l|l|l|}
\hline $\mathbf{N r}$ & Name & Variable Type & Source \\
\hline 35.1 & infringement of the cartel clause & integer & agreement \\
\hline 35.2 & provision of false data & integer & agreement \\
\hline 35.3 & refusal to provide information & integer & agreement \\
\hline
\end{tabular}

Table 36: Relative penalties (Upper Limits, in percent of)

\begin{tabular}{|l|l|l|l|}
\hline $\mathbf{N r}$ & Name & Variable Type & Source \\
\hline 36.1 & deviation from the cartel clause & integer & agreement \\
\hline 36.2 & $\begin{array}{l}\text { deviation from revenues agreed } \\
\text { upon }\end{array}$ & integer & agreement \\
\hline
\end{tabular}

In many cases, penalties were specified to be paid directly by the firms. In some cases, however, the cartel organization required a security deposit per participating firm ("Kaution") to ensure the immediate payment of a penalty. Surprisingly, that security deposit (in form of a bill of exchange) was sometimes unlimited, as specified in Table 37. 
Table 37: Penalties: Security deposits

\begin{tabular}{|l|l|l|l|}
\hline $\mathbf{N r}$ & Name & Variable Type & Source \\
\hline 37.1 & $\begin{array}{l}\text { upper limit of the security de- } \\
\text { posit }\end{array}$ & integer & agreement \\
\hline 37.2 & unlimited security deposit & binary & agreement \\
\hline
\end{tabular}

\subsection{Entry into, and Exit from the Cartel}

Table 38 refers to conditions specified in the cartel contract, under which a potential entrant could become a member of the cartel. We consider conditions ('minimal entry requirements') that had to be fulfilled by the potential entrants, and clauses where the approval of entry was subject to discussion in some cartel body. Note that these categories are not mutually exclusive.

Table 38: Voluntary Entry/Exit: Rules for Entry

\begin{tabular}{|l|l|l|l|}
\hline $\mathbf{N r}$ & Name & Variable Type & Source \\
\hline 38.1 & minimal entry requirements & binary & agreement \\
\hline 38.2 & entry subject to approval & binary & agreement \\
\hline
\end{tabular}

We code information on exit in Table 39. In several cases a cartelist had to announce its exit in advance. We code the period of notice of withdrawal (in months). Furthermore, several cases permitted exit only at certain dates with a long interval period in between. Such a typical case involves the possibility to exit only at the end of every other year with a three months notice. ${ }^{27}$ Finally, we code for clauses that allow for exits of other cartelists subsequent to an exit of a particular firm.

Table 39: Voluntary Entry/Exit: Rules for Exit

\begin{tabular}{|l|l|l|l|}
\hline $\mathbf{N r}$ & Name & Variable Type & Source \\
\hline 39.1 & period of notice (in months) & integer & agreement \\
\hline 39.2 & $\begin{array}{l}\text { calculated interval between exit } \\
\text { dates (years) }\end{array}$ & integer & agreement \\
\hline 39.3 & subsequent exit allowed & binary & agreement \\
\hline
\end{tabular}

\footnotetext{
${ }^{27}$ In a few vertical agreements, the withdrawal notice for the upstream manufacturer and that ofthe downstream trading partner differ, e.g. upstrem: 3 months, donwstream: 6 months. We took the withdrawal notice for the upstream manufacturer.
} 